\title{
Improvement of elements of technology of cultivation of Thymus vulgaris $L$. under irrigation conditions
}

\author{
Pryvedeniuk N. ${ }^{1}$, Hlushchenko L. ${ }^{2}$ \\ The Research Station of Medicinal Plants of Institute of Agroecology and Environmental Management \\ of NAAS \\ 16a Pokrovska Str., Berezotocha vill., Lubenskyi region, Poltava oblast, Ukraine, 37535 \\ e-mail: ${ }^{1}$ privedenyuk1983@gmail.com, 2 1256@ukr.net \\ ORCID: ${ }^{1}$ 0000-0002-0748-8083, ${ }^{2}$ 0000-0003-2329-5537
}

Goal. To improve the elements of the technology of growing Thymus vulgaris $\mathrm{L}$. by establishing the optimal area of plant nutrition, the dose of the main application of mineral fertilizers, at the seedling method of propagation under drip irrigation. Methods. The research used methodological approaches that are traditionally used in domestic agricultural practice and in medicinal crop production. In particular, the development of experimental schemes was performed according to the methods of B.O. Dospekhova and M.M. Horianskyi, sampling of plants, biometric measurements, and yield accounting were carried out taking into account the characteristics of medicinal crops according to the methods of A.I. Brykin and O.A. Porada. The moisture content of the root layer of the soil during the growing season was maintained at the level of $75-80 \%$ of the lowest moisture content. Results. Based on the conducted researches, the dependence of the yield of Thymus vulgaris $L$. on the area of plant nutrition and doses of the main application of mineral fertilizers was established. It was fixed that with the increase in the number of plants per unit area (hectare), the yield of dry raw of Thymus vulgaris L. increased. The highest yield of grass in the first year of the growing season was obtained at a density of 222 thousand plants/ha. In the second year - the highest yield of the dried grass of Thymus vulgaris $\mathrm{L}$. was obtained at a density of 111 thousand plants/ha. When specifying the doses of the main application of mineral fertilizers for the cultivation of Thymus vulgaris $L$. a dependence was revealed - with the increase of the dose of fertilizers, crop yields increased. In the control variant (without the main application of mineral fertilizers) the yield of raw materials (dry grass) was 3.19 $\mathrm{t} / \mathrm{ha}$ in the 1 st year of vegetation and $3.73 \mathrm{t} / \mathrm{ha}$ - in the $2 \mathrm{nd}$. The highest yield of Thymus vulgaris $\mathrm{L}$. was obtained at the use of main mineral fertilizer in a dose of N180P180K180, which was $4.69 \mathrm{t} / \mathrm{ha}$ in the 1st year of vegetation, and $5.82 \mathrm{t} / \mathrm{ha}$ - in the $2 \mathrm{nd}$. Conclusions. It is proved that the improved elements of the technological process of growing Thymus vulgaris $L$. under irrigation conditions provide high yields of raw materials. In particular, it is necessary to adjust the planting density, which provides the optimal feeding area of the crop - from 111 thousand plants/ha to 222 thousand plants/ha, and to ensure the main application of mineral fertilizers in a dose of N180P180K180.

Key words: seedling method of reproduction, mineral fertilizers, feeding area, cultivation scheme, yield.

DOI: https://doi.org/10.31073/agrovisnyk202101-04

There are more than 360 species of the thyme genus in the world. The most common in the culture is Thymus vulgaris [1-3]. Thymus vulgaris is a perennial plant family labiate. In natural conditions it grows in the Mediterranean countries [4, 18], in Ukraine it occurs only in culture conditions [5-7]. Aboveground parts of plants - grass or threshing (leaves from inflorescences and small twigs) - Herba Thymi vulgari (Thymi herba) are raw materials of thyme for medicinal and essential oils. The composition of thyme basic biologically active substances includes such essential oils as carvacrol and thymol $[1,5,7,8]$.

Annual world production of raw thyme is approximately 1500 tons of dry grass and 30 tons of essential oils $[9,10]$. Dry raw materials and essential oils thyme are used in pharmaceutical, cosmetic and perfumery industry, as well as in food industry as a spice and for cooking spices mixtures [11]. This culture has enough significant spread in the world, which indicates it high plasticity to various conditions environment.

Fine seed (small-seededness) is quite common among medicinal plants. Due to that feature the seed material needs special germination conditions. This complicates the process of reproduction through direct sowing seeds in open ground, so plantations of the vast majority of perennial medicinal cultures should be planted by seedlings with applying of irrigation [12,13]. Thyme is a representative of such cultures. Nowadays there is a need to investigate establishing the optimal nutrition area, schemes for thyme growing under drip irrigation, as well as determination of mineral fertilizers effective doses and other elements of cultivation technology of the culture under the conditions of rapid climate change.

Researchers from Lithuania, the Czech Republic, Iran, Egypt, Turkey and other countries are making research to improve the technology of growing thyme by conventional application of mineral fertilizers, irrigation, and growth regulators. In particular, the effect of nitrogen fertilizers on the yield and quality of raw thyme material was studied by Lithuanian scientists, who found that the application of nitrogen increased the yield of dry grass and increased the yield of essential oil per unit area [14]. The team of scientists from 
the Institute of Plant Breeding (the Czech Republic) has been established the effect of foliar application of nitrogen, phosphorus, potassium and salicylic acid on the performance of thyme. Foliar fertilization increased the content of essential oils in comparison to the control samples by $18,76-42,47 \%$ [15]. Iranian researchers (Islamic Azad University, Shahrekord Branch) proved the efficiency of application of organic and mineral fertilizers for thyme growing. It was shown that organic fertilizers are more effective than mineral fertilizers. The highest yield of dry raw materials and the yield of essential oils were shown in the experiment with the introduction of phosphate-solubilizing bacteria, nitroxine and humus [16]. Thyme is fairly resistant to adverse environmental conditions, but its resistance to soil salinity increases foliar application of potassium chloride and calcium chloride. This regularity was discovered by studies of scientists from Tunisia, Saudi Arabia and the United States [17]. In Jordan during 2007 - 2008 researchers also tried to improve the technology of thyme growing by finding the optimal nutrition area. It was found that the highest yield of raw materials provided the nutrition area with a row spacing of $15 \mathrm{~cm}$, both on the 1st and 2 nd year of vegetation culture [18]. Interesting research results on the influence of the irrigation intervals and planting density on the yield of thyme were obtained by Iranian researchers. It was proved that with the increase of plants dense, the weight of plants and the content of essential oil decreased, and the change in the intervals of irrigation periods did not affect crop yields [19]. In Ukraine, on the basis of Kherson Agrarian University, the affect of mineral and organic fertilizers, depth of the main tillage, sowing periods and row spacing on the productivity of thyme in the steppe zone conditions was studied. It was found that the simultaneous application of manure and mineral fertilizers with a plowing depth of $28-30 \mathrm{~cm}$ improves water and nutrient regimes of the soil, provides effective protection of crops from weeds and helps to maintain the highest crop yields and quality of raw materials [5, 6].

The aim of the study is to improve the elements of the thyme growing technology by establishing the optimal area of plant nutrition, the dose of the mineral fertilizers main application and by the seedling method of reproduction under drip irrigation.

Materials and methods. Field research was carries out during 2019 - 2020 in the fields of the Research Station of the Medicinal Plants of the Institute of Agroecology and Nature Management of NAAS (Ukraine, Poltava region, Lubny district).

The soil of the experimental field is strong, low-humus chernozem, the thickness of the humus horizon is $87-100 \mathrm{~cm}$, light in particle size distribution. The reaction of the soil solution is weakly acidic, the metabolic acidity of the soil is characterized as moderately acidic. The supply of the soil with basic nutrients: easily hydrolyzed nitrogen - low, mobile phosphorus - very high, exchangeable potassium - increased. According to the amount of salts, the soil belongs to unsalted soils. The lowest moisture content $(\mathrm{HB})$ of the soil layer of $0-100 \mathrm{~cm}$ is $18,2 \%$, for $0-50 \mathrm{~cm}$ layer $-17,5 \%$, the density of formation is $1,32 \mathrm{~g} / \mathrm{cm}^{3}$.

The methods of Dospekhova B.O. and Goryansky M.M. were used to develop experimental schemes. Selection of plant samples, biometric measurements and phenological observations were carried out considering the peculiarities of medicinal cultures according to the methods of Brikina A.I. and Porada O.A. [20 - 23].

The experimental field was planted with seedlings in open ground in the first decade of May. Planting schemes: $45 \times 40 \mathrm{~cm}-56$ thousand plants/ha; $45 \times 30 \mathrm{~cm}-74$ thousand plants/ha; $45 \times 20-111$ thousand plants/ ha and $45 \times 10 \mathrm{~cm}-222$ thousand plants/ha.

The main mineral fertilizers application of Nitroammophoska $\mathrm{N}_{16} \mathrm{P}_{16} \mathrm{~K}_{16}$ was carried out for pre-planting cultivation in doses $\mathrm{N}_{60} \mathrm{P}_{60} \mathrm{~K}_{60}, \mathrm{~N}_{120} \mathrm{P}_{120} \mathrm{~K}_{120}$ and $\mathrm{N}_{180} \mathrm{P}_{180} \mathrm{~K}_{180}$, the control group was without application of any mineral fertilizers.

The total size of the plots is $35-55 \mathrm{~m}^{2}$, the accounting size is $20-35 \mathrm{~m}^{2}$ for 4 times repetitions. Locations of plots were randomized.

During the growing season, soil moisture (for layer $0-40 \mathrm{~cm}$ ) was maintained at $75-80 \%$ of the lowest moisture content, using a drip irrigation system. One irrigation pipeline moistened 2 rows of plants. Soil moisture was monitored using tensiometers

Accounting for crop yields was carried out in the thyme flowering phase, mowing the aboveground mass at a height of $5 \mathrm{~cm}$ from soil surface. Standardized humidity of raw materials $10-12 \%$ was provided using a natural method of drying.

Results. Study of the influence of plant nutrition on yield showed the dependence between increase in number of plants per unit area and increase of the thyme grass yield. It was especially noticeable in the 1st year of the growing season. In the variant with a planting density of 56 thousand plants/ha (according to the scheme of cultivation $45 \times 40 \mathrm{~cm}$ ), the yield of dry grass for the 1 st year of growing was $1,70 \mathrm{t} / \mathrm{ha}$, with an increase in the number of plants to 74 thousand plants/ha $(45 \times 30 \mathrm{~cm})$, grass yield increased to $2,46 \mathrm{t} / \mathrm{ha}$. In the variant with plant density of 111 thousand plants/ha $(45 \times 20 \mathrm{~cm})$ yield of dry raw materials ha was $3,05 \mathrm{t} / \mathrm{ha}$, the highest yield of dried thyme grass was $3,37 \mathrm{t} / \mathrm{ha}$ for the 1 st year of vegetation was obtained in the variant with the highest plant density of 222 thousand plants $/ \mathrm{ha}(45 \times 10 \mathrm{~cm})($ Table 1$)$. 
1. The effect of plants nutrition area on thymus grass yield

\begin{tabular}{|c|c|c|}
\hline \multirow{2}{*}{ Variant } & \multicolumn{2}{|c|}{ Grass yield, t/ha } \\
\cline { 2 - 3 } & $1^{\text {st }}$ vegetation year & $2^{\text {nd }}$ vegetation year \\
\hline $45 \times 40 \mathrm{~cm}(56$ thousand plants/ha $)$ & 1,70 & 3,56 \\
\hline $45 \times 30 \mathrm{~cm}(74$ thousand plants/ha) & 2,46 & 4,89 \\
\hline $45 \times 20 \mathrm{~cm}(111$ thousand plants/ha) & 3,05 & 5,12 \\
\hline $45 \times 10 \mathrm{~cm}(222$ thousand plants/ha $)$ & 3,37 & 5,03 \\
\hline HIP 0,5 & 0,12 & 0,08 \\
\hline
\end{tabular}

For the 2nd year of thyme vegetation in the variant of 56 thousand plants/ha, the yield of dry grass was $3,56 \mathrm{t} / \mathrm{ha}$, an increase in number of plants up to 74 thousand plants/ha ensured the harvest at the level of $4,89 \mathrm{t} / \mathrm{ha}$. The highest yield of dried thyme $-5,12 \mathrm{t} / \mathrm{ha}$ for the 2 nd year of the growing season was obtained in the variant with the planting of 111 thousand plants/ha. Further increase in number of plants per unit area only reduced the yield and quality of raw materials.

The dependence of the plant nutrition area on the thyme grass yield is described mathematically by the following equations:

$y=-1 E-10 x^{2}+5 E-05 x-0,3787, R^{2}=0,98-1$ st year of vegetation;

$y=-2 E-10 x^{2}+6 E-05 x+1,2043, R^{2}=0,80-2$ nd year of vegetation,

where $y$ is the yield of dry grass, $t / h a ; x$ - number of plants, thousand/ha; $R^{2}-$ the value of the reliability of the approximation.

The value of the approximation is 0,80 and 0,98 , which indicates the high reliability of the yield of dried thyme grass on the number of plants per unit area. Performed mathematical calculations can be used to predict crop yields (Fig. 1).

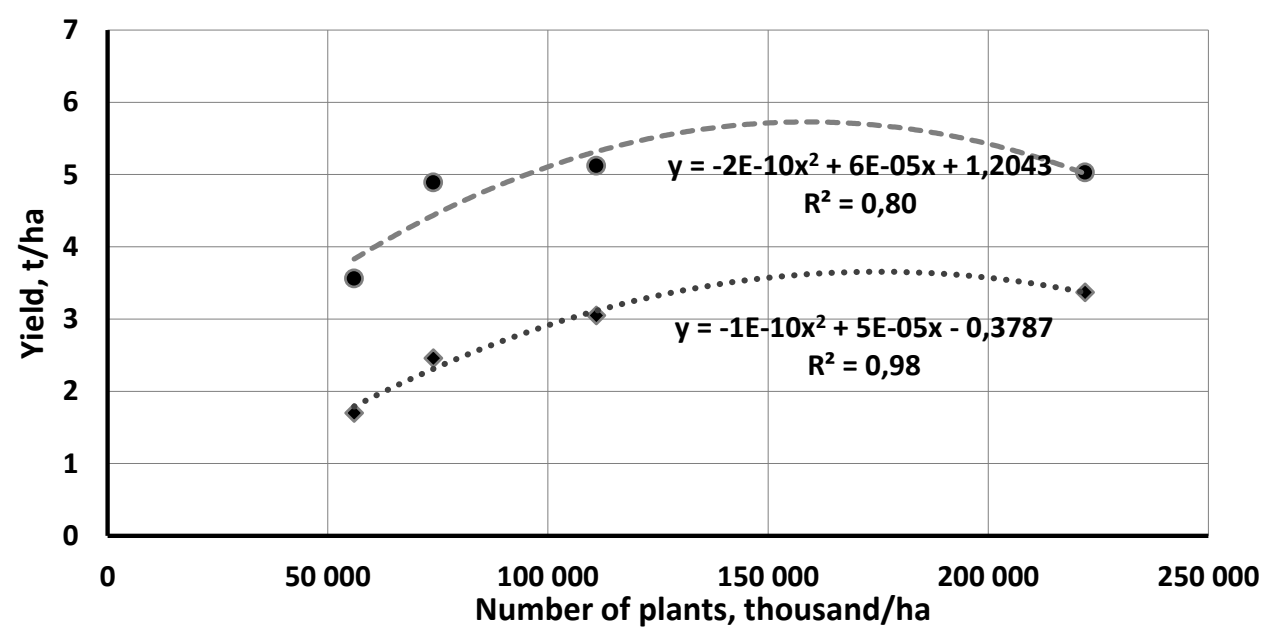

Fig. 1. The effect of planting density per unit area on thymus grass yield: $\bullet$ for the $1^{\text {st }}$ vegetation year; - for the $2^{\text {nd }}$ vegetation year

The dependence of the main mineral fertilizers application on the yield of thyme was revealed during the study: increase of the fertilizer dose application increased the yield. For the 1st year of vegetation on the control variant (without the mineral fertilizers main application) the yield of dry grass was 3,19/ha, the mineral fertilizer main application at a dose of $\mathrm{N}_{60} \mathrm{P}_{60} \mathrm{~K}_{60}$ increased the yield to $3,67 \mathrm{t} / \mathrm{ha}$, which exceeded the control by $15 \%$. In the variant with the application of $\mathrm{N}_{120} \mathrm{P}_{120} \mathrm{~K}_{120}$, the yield was $4,22 \mathrm{t} / \mathrm{ha}$; the highest yield of dried thyme grass for the 1 st year of vegetation was $4,69 \mathrm{t} / \mathrm{ha}$, which exceeded the control by $47 \%$, it was provided by the highest dose of the mineral fertilizers main application of $\mathrm{N}_{180} \mathrm{P}_{180} \mathrm{~K}_{180}$ (Table 2).

\section{The effect of main mineral fertilizers application on the thymus yield}

\begin{tabular}{|c|c|c|c|c|}
\hline \multirow{2}{*}{ Variant } & \multicolumn{2}{|c|}{$1^{\text {st }}$ year of vegetation } & \multicolumn{2}{c|}{$2^{\text {nd }}$ year ofvegetation } \\
\cline { 2 - 5 } & grass yield, $\mathrm{t} / \mathrm{ha}$ & $\%$ to conrol & grass yield, $\mathrm{t} / \mathrm{ha}$ & $\%$ to control \\
\hline $\mathrm{N}_{0} \mathrm{P}_{0} \mathrm{~K}_{0}$ (control) & 3,19 & 100 & 3,73 & 100 \\
\hline $\mathrm{N}_{60} \mathrm{P}_{60} \mathrm{~K}_{60}$ & 3,67 & 115 & 4,28 & 115 \\
\hline $\mathrm{N}_{120} \mathrm{P}_{120} \mathrm{~K}_{120}$ & 4,22 & 132 & 5,17 & 139 \\
\hline $\mathrm{N}_{180} \mathrm{P}_{180} \mathrm{~K}_{180}$ & 4,69 & 147 & 5,82 & 156 \\
\hline $\mathrm{HIP}_{0,5}$ & 0,10 & & 0,12 & \\
\hline
\end{tabular}


For the control of the $2 \mathrm{nd}$ vegetation year, the yield of raw thyme was $3,73 \mathrm{t} / \mathrm{ha}$. The application of mineral fertilizers helped to increase yield. Thus, with the application of mineral fertilizers at a dose of $\mathrm{N}_{60} \mathrm{P}_{60} \mathrm{~K}_{60}$, the grass yield was $4,28 \mathrm{t} / \mathrm{ha}$, which exceeded the control by $15 \%$ or $0,55 \mathrm{t} / \mathrm{ha}$. Increase of the dose of fertilizer up to $\mathrm{N}_{120} \mathrm{P}_{120} \mathrm{~K}_{120}$ increased the yield of dry grass to $5,17 \mathrm{t} / \mathrm{ha}$, which exceeded the control by $39 \%$ or $1,44 \mathrm{t} / \mathrm{ha}$. The highest yield of thyme for the $2 \mathrm{nd}$ year of vegetation was $5,82 \mathrm{t} / \mathrm{ha}$ was obtained in the variant with the application of mineral fertilizer at a dose of $\mathrm{N}_{180} \mathrm{P}_{180} \mathrm{~K}_{180}$.

The dependence of the doses of the mineral fertilizers main application on the yield of dried thyme grass can be described mathematically by equations:

$y=0,0119 x+3,676, R^{2}=0,97-$ for the 1 st year of vegetation;

$y=-7 E-07 x^{2}+0,0085 x+3,1825, R^{2}=0,98-$ for the 2 nd year of vegetation,

where $y$ is the yield of dry grass, t/ha; $x$ - dose of the mineral fertilizers main application NPK $\mathrm{kg} / \mathrm{ha}$ of active substance; $R^{2}$ - value reliability of approximation.

The value of the approximation is 0,97 and 0,98 , which indicates a high reliability of the dry thymus grass yield from the main application of mineral fertilizers (Fig. 2).

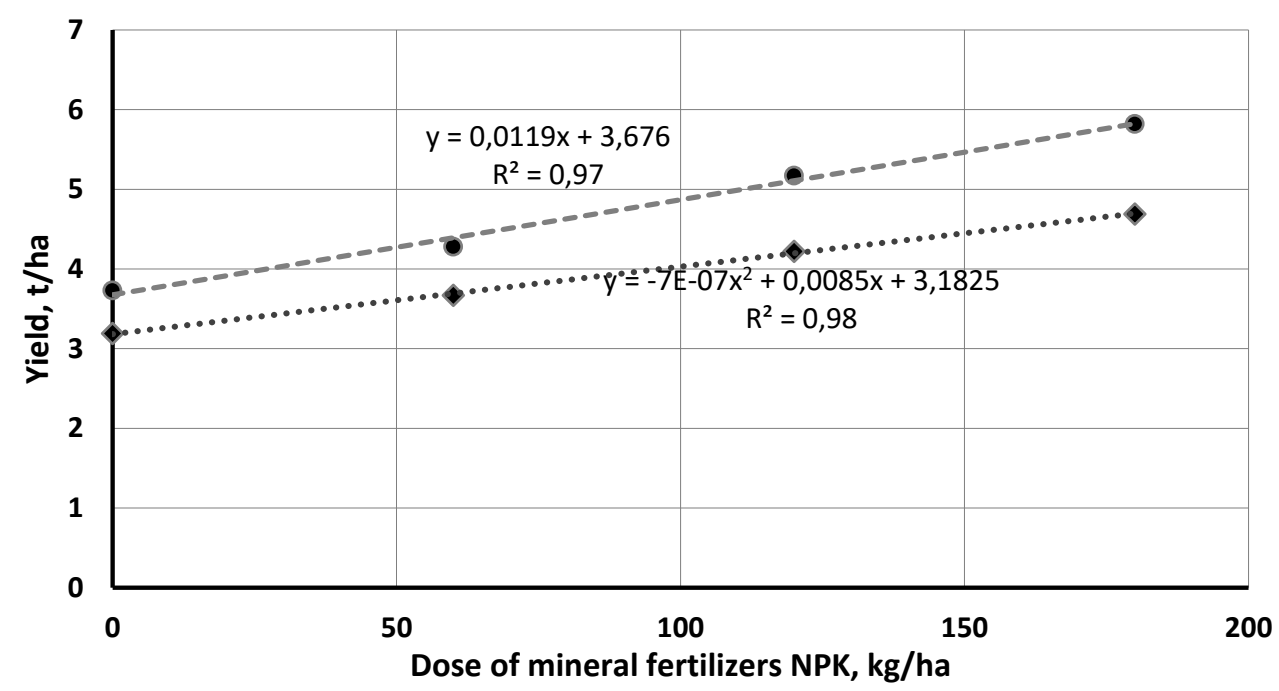

Fig. 2. The effect of main mineral fertilizers dose on thymus yield: - the $1^{\text {st }}$ year of vegetation; - the $2^{\text {nd }}$ year of vegetation

For the production of medicines based on thyme, Ukrainian pharmaceutical industry uses mostly the aboveground part (dry grass), as for European pharmaceutical companies - threshing (leaves, inflorescences and small twigs separated from the stems), so during the study for accounting conducted a structural analysis of raw materials.

The study of the influence of plant nutrition on the yield of marketable raw materials - threshing (leaves with inflorescences) showed that increasing of the area of plant nutrition contributed to increase of the yield of marketable raw materials. In the variant with the smallest nutrition area - the scheme of cultivation $45 \times 10$ $\mathrm{cm}$, the share of marketable raw materials was the smallest and amounted to $45,1 \%$. The increase in the nutrition area in the variant with a cultivation scheme of $45 \times 20 \mathrm{~cm}$ contributed to an increase in the share of marketable raw materials to $47,7 \%$. The variant with the largest nutrition area had the highest raw material yield of $52,3 \%$. Such conditions were optimal for thyme plants formation of aboveground mass and leaf apparatus (Fig. 3).

Studies have shown that the increase in the share of marketable raw materials depends on the mineral fertilizers main application. With mineral fertilizers dose increase the share of $c$ marketable raw materials for aboveground plant mass of culture. For the control - without fertilizers, the share of raw materials was $46,3 \%$, in the variant with the application of fertilizers at a dose of $\mathrm{N}_{60} \mathrm{P}_{60} \mathrm{~K}_{60}$, the share of raw materials increased and was at the level of $47.9 \%$. Increasing the application of mineral fertilizers dose to $\mathrm{N}_{120} \mathrm{P}_{120} \mathrm{~K}_{12} \mathrm{O}$ contributed to the increase of the share of marketable raw materials to $51,6 \%$. The largest share $(52,8 \%)$ was obtained in the variant with the highest application dose of mineral fertilizers $-\mathrm{N}_{180} \mathrm{P}{ }_{180} \mathrm{~K}_{180}$. 


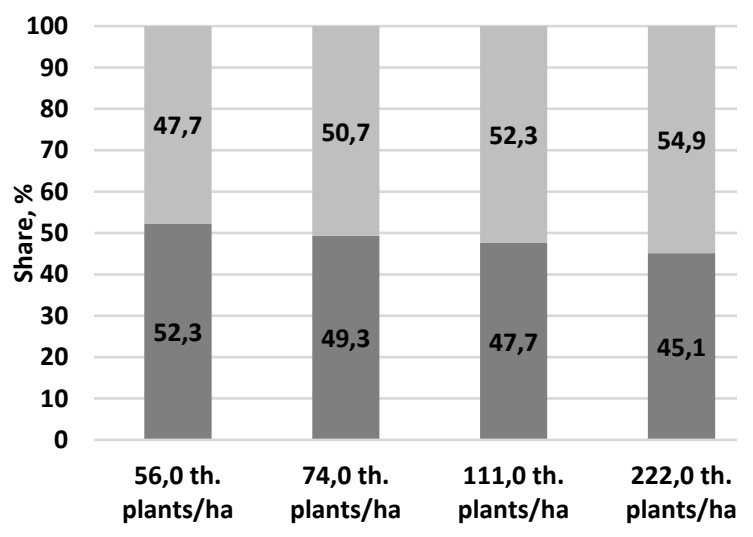

a

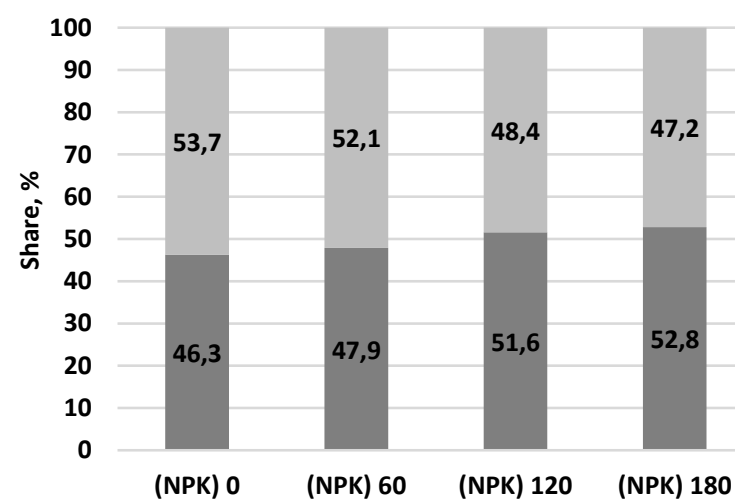

b

Fig. 3. Yield structure for thymus raw material depending on nutrition area (a) and main mineral fertilizers application (b) under conditions of drip irrigation: - leaves, \%; $\quad$ - stems, \%

\section{Conclusions}

A number of experiments were carried out to improve the growing technology elements for thyme. Result of the study revealed certain dependences, in particular the number of planted plants per unit area on the yield of dry grass, which is described by the equation $y=-1 E-10 x^{2}+5 E-05 x-0,3787, R^{2}=0,98$ - for the 1st year of vegetation; $y=-2 E-10 x^{2}+6 E-05 x+1,2043, R^{2}=0,80-$ for the 2nd year of vegetation, where $y$ is the yield of dry grass, t/ha; $x$ - number of plants, thousand plants/ha. The highest yield of dry thyme grass 5,12 t/ha for the $2 n d$ year of vegetation was obtained in the variant with a density of 111 thousand plants/ha. The mineral fertilizers main application also to helped to increase the yield of thyme. The revealed dependence is described by the equation $y=0,0119 x+3,676, R^{2}=0,97-$ for the 1 st year of vegetation; $y=-7 E-07 x^{2}+0,0085 x+3,1825, R^{2}=0,98-$ for the $2 n d$ year of vegetation, where $y$ is the yield of dry grass, t/ha, $x$ - doses of the main application of mineral fertilizers NPK $\mathrm{kg} / \mathrm{ha}$ of active substance. The most effective dose of mineral fertilizers was $N_{180} P_{180} K_{180}$, where the yield of dry grass in the 1st year of the growing season was 4,69 t/ha, and for the $2 n d-5,62 t / h a$. The effect of the plant nutrition area on the share of raw materials (leaves, inflorescences and small twigs) was revealed. The highest $(52,3 \%)$ share was in the variant with the lowest planting density per unit area.

\section{References}

1. Popova, N.V., Litvinenko, V.I., \& Kutsanyan, A.S. (2016). Lekarstvennye rasteniya mirovoy flory [Medicinal plants of the world flora]. Kharkov: Dysa plyus. [In Russian].

2. Lawrence, B.M., \& Tucker, A.O. (2002). The genus Thymus as a source of commercial products. Thyme, the genus Thymus. Taylor \& Francis. London.

3. Zarzuelo, A., \& Crespo, E. (Stahl-Biskup, E. and Saez, F. (Eds.)). (2002). The medicinal and non medicinal uses of thyme. In thyme. The genus Thymus. Medicinal and Aromatic Plants Industrial Profiles. New York: Taylor and Francis.

4. Hosseinzadeh, S., Jafari Kukhdan, A., Hosseini, A., \& Armand, R. (2015). The Application of Medicinal Plants in Traditional and Modern Medicine: A Review of Thymus vulgaris. International $\mathrm{J}$. of Clinical Medicine, 06(09), 635 - 642.

5. Chaban, V.O. (1999). Rozrobka ahrotekhnichnykh pryiomiv vyroshchuvannia tymiana zvychainoho pry zroshenni $v$ umovakh pivdnia Ukrainy [Development of agrotechnical methods of growing common thyme under irrigation in the south of Ukraine]. Taurian Scientific Bulletin. Kherson: Ailant, 11(1), $85-87$.

6. Chaban, V.O. (1998). Biolohichni osoblyvosti nakopychennia efirnoi olii v tymiani zvychainomu pry riznykh pryiomakh vyroshchuvannia v umovakh zroshennia Pivdnia Ukrainy [Biological features of the accumulation of essential oil in common thyme under different methods of cultivation under irrigation in the South of Ukraine]. Taurian Scientific Bulletin. Kherson: Ailant, 5(2), 25 - 26. [In Ukrainian].

7. Tymchenko, I.A., Hlushchenko, L.A., Minarchenko, V.M., \& Anishchenko, T.M. (2007). Monitorynh resursiv vydiv rodu Thymus $L$. $v$ Ukraini [Monitoring of resources of species of the genus Thymus $L$. in Ukraine]. Ukr. botan. magazine, 64(1), 78 - 87. [In Ukrainian].

8. Bondarieva, L.M. (2017). Vyvchennia kompleksu makro-skopichnykh ta mikroskopichnykh diahnostychnykh oznak chebretsiu zvychainoho (Thymus vulgaris L.) u skladi likarskoi roslynnoi syrovyny «Thymi herba» [Study of the complex of macroscopic and microscopic diagnostic features of thyme (Thymus vulgaris L.) in the composition of medicinal plant raw materials "Thymi herba"]. Bulletin of Sumy National Agrarian University. Ser. "Agronomy and Biology". Sumy: SNAU, 2 (33), 17 - 22. [In Ukrainian].

9. Mc Gimpsey, J. (1993). Thyme-Thymus vulgaris. URL: http://www.crop.cri.n2/broadshe/thyme.htm 
10. Ministry of Agriculture Jihad (MAJ). (2015). Com-munications and information technology center. URL: http://amar.maj.ir/ Portal/Home/Default.aspx?

11. Nickavar, B., Mojab, F., \& Dolat-Abadi, R. (2005). Analysis of the essential oils of two Thymus species from Iran. Food Chemistry, 90, $609-611$.

12. Pryvedeniuk, N.V., \& Shatkovskyi, A.P. (2020). Vplyv ploshchi zhyvlennia materynky zvychainoi (Origanum vulgare L.) na rist ta rozvytok $v$ umovakh kraplynnoho zroshennia [Influence of feeding area of oregano (Origanum vulgare L.) on growth and development in conditions of drip irrigation]. Land reclamation and water management. Kyiv, 1, 68 - 75. [In Ukrainian].

13. Pryvedeniuk N.V., Hlushchenko L.A., \& Trubka V.A. (2020). Vplyv sposobiv vyroshchuvannia rozsady ta ploshchi zhyvlennia na rist ta rozvytok melisy likarskoi (Melissa officinalis L.) $v$ umovakh kraplynnoho zroshennia [Influence of seedling cultivation methods and feeding area on the growth and development of Melissa officinalis L. under the conditions of drip irrigation]. Agroecological journal. Kyiv, 1, $91-97$.

14. Baranauskiene, R., Venskutonis, P.R., Viskelis, P., \& Dambrauskiene, E. (2004). Influence of Nitrogenon the Yield and Composition of Thyme (Thymus vulgaris). J. of agricultural and food chemistry, 51 (26), 7751 - 7759.

15. Pavela, R., Zabka, M., Vrchotova, N., \& Tríska, J. (2018). Effect of foliar nutrition on the essential oil yield of Thyme (Thymus vulgaris L.). Industrial Crops and Products, 112, $762-765$.

16. Yadegari, Mehrab \& Farahani, G.H.N. \& Mosadeghzad, Z. (2012). Biofertilizers effects on quantitative and qualitative yield of Thyme (Thymus vulgaris). African J. of Agricultural Research, 7, 4716 - 4723.

17. Ahlem, Zrig, Jorge, F.S. Ferreira, Foued, Hamouda et al. (2019). The impact of foliar fertilizers on growth and biochemical responses of Thymus vulgaris to salinity stress. Arid Land Research and Management, 33(3), 297 - 320.

18. Ezz AL-Dein Muhammed Al-Ramamneh (2009). Plant growth strategies of Thymus vulgaris $L$. in response to population density. Industrial Crops and Products, 30(3), $389-394$.

19. Khazaie, H.R., Nadjafi, F., \& Bannayan, M. (2008). Effect of irrigation frequency and planting density on herbage biomass and oil production of thyme (Thymus vulgaris) and hyssop (Hyssopus officinalis). Industrial Crops and Products, 27(3), 315 - 321.

20. Brikin, A.I. (1981). Provedenie polevykh opytov s lekarstvennymi kulturami [Conducting field experiments with medicinal crops]. Mjcrdf: TsBNTIMP. [In Russian].

21. Goryanskiy, M.M. (1970). Metodika polevykh opytov na oroshaemykh zemlyakh [Methodology of field experiments on irrigated lands]. Kiev: Urozhay. [In Russian].

22. Dospekhov, B.A. (1985_. Metodika polevogo opyta (s osnovami statisticheskoy obrabotki rezultatov issledovaniy). [Field experiment technique (with the basics of statistical processing of research results)]. Moscow. Agropromizdat. [In Russian].

23. Porada, O.A. (2007). Metodyka formuvannia i vedennia kolektsii likarskykh Roslyn [Methods of forming and maintaining collections of medicinal plants]. Poltava: PDAA. [In Ukrainian]. 